\title{
Human Resources during COVID-19: A Monthly Survey on Mental Health and Working Attitudes of Czech Employees and Managers during the Year 2020
}

\author{
Marcel Rolf Pfeifer (D)
}

check for updates

Citation: Pfeifer, M.R. Human Resources during COVID-19: A Monthly Survey on Mental Health and Working Attitudes of Czech Employees and Managers during the Year 2020. Sustainability 2021, 13, 10055. https://doi.org/10.3390/ su131810055

Academic Editors: Emanuele Cannizzaro, Tiziana Ramaci,

Massimiliano Barattucci, Fulvio

Plescia, Haywantee Ramkissoon, Lotfi Aleya and Christian Vandenberghe

Received: 29 July 2021

Accepted: 3 September 2021

Published: 8 September 2021

Publisher's Note: MDPI stays neutral with regard to jurisdictional claims in published maps and institutional affiliations.

Copyright: (C) 2021 by the author. Licensee MDPI, Basel, Switzerland. This article is an open access article distributed under the terms and conditions of the Creative Commons Attribution (CC BY) license (https:// creativecommons.org/licenses/by/ $4.0 /)$.
Department of Management, Faculty of Business and Management, Brno University of Technology, 61200 Brno, Czech Republic; pfeifer@vutbr.cz

\begin{abstract}
This study investigates the effect of COVID-19 lockdowns and non-lockdown phases on managers and employees in the Czech Republic in the year 2020. The Czech Republic came through the first COVID-19 wave in spring 2020 with low case numbers, but became one of the countries with the highest case incidences in the second autumn wave in Europe. The study focused on examining the differences of perceptions on digital readiness of the company, working style, and mental health variables of working personnel in lockdown and non-lockdown phases. Data was obtained by an online survey conducted monthly from March-2020 to December-2020 with the same questions each month. Collected data consisted of respondents' basic information on the actual situation, on perceptions on company and technology and on perceptions of the own mental state in the given month, retrieved from a pool of employees and managers from the Czech Republic machine and equipment manufacturers' industry. Statistical analysis was conducted with the Kruskal-Wallis test for ordinal variables to check for significant differences in perceptions during 2020. Results show that managers in general and telecommuting-experienced workers in particular are better able to adapt to forced home office, while telecommuting-inexperienced employees struggle to adapt positively even with increasing company support and with an increasing digital team communication.
\end{abstract}

Keywords: human resource; telecommuting; COVID-19; home-office; lockdown; stress; mental health

\section{Introduction}

In 2020, the World Health Organization (WHO) announced the COVID-19 epidemic to be a pandemic [1,2]. Several countries all over the world began to take countermeasures by applying e.g., lockdowns [3]. European countries took measures against the pandemic by restricting private, social, and work life. Social and work life was locked down to prevent a further spreading of the virus [4]. Following Italy, which took the lead in absolute numbers of infected people in this first COVID-19-wave in Europe, several other countries applied similar measures [5]. Full or partial lockdowns (also referred to as shutdowns) were imposed [6]. Imposed government rules to keep distance among employees and to keep distance between employees and company externals as well as the immediate decrease in demand from customers forced companies and governments to find a solution to the situation [7]. In order to prevent employees from meeting each other directly, employees were sent home for telework from home (also referred to as home office), belonging to the governments' stay-at-home orders for their population [8]. The lockdowns had economywide impacts and affected employees and managers from small, middle-sized, and big companies at the same time by sending them on forced home office.

Sending employees into a home office framework exposed these employees to a framework similar as it is known from previously-studied telecommuting [9], where workers did not have a fixed workplace [10]. Companies and company management had to take measures in order to adjust their business processes according to new requirements. Companies that were used to work only in a daily office framework missed IT-infrastructure [11] and 
were organizationally not prepared for a widespread home office working [12]. Employees that were not used to working at home were now forced to do so. Without planning and mostly without training, employees were sent on home office without knowledge of a home office infrastructure [13]. Also, managers were forced into home offices, having to care for a whole team being sent to sudden home office without preparation [14]. Additionally, schools closed, sending children home, where their parents worked in home offices [15].

With the movement to a sudden home office framework and the imposure of countrywide lockdowns, workers had to adapt to the new living and working style style [16]. People showed significantly-increased tendencies towards depression, psychical stress, and anxiety [17]. The policy of social distancing did not allow for private physical contact but allowed only for digital ways to maintain relationships. Additionally, workers had to switch to a digital environment for working purposes. This also included the mere digital contact with further organization and team members [14]. Workers transferring from a daily home office job were exposed to changes in an even higher level than workers coming from a telecommuting framework. However, depending on the country of operation, different rulesets were available to choose which way telework, home office, and further instruments could be applied [18]. The German instrument of "Kurzarbeit" (English translation: Short work) allowed companies to send their employees on paid vacation to a certain extent while the German state took over part of the salary [19]. Similar instruments were applied in other European countries [20]. Also, part of the Czech industry worked in a framework of short work, while the major concern was with the disruption of supply chains and coordination issues with international colleagues not being present and international production halls being closed [21].

The Czech Republic was able to come through the first pandemic wave in spring 2020 with a low case incidence rate and with a lockdown. Between May 2020 and October 2020, the Czech Republic went into a non-lockdown phase. In autumn 2020, it became the European country with the highest case incidence rates and a second lockdown began in October-2020. Social contacts had to be reduced [22]. Similar telecommuting frameworks in work are known to have ambiguous impacts on different employees. While one part of employees sees telecommuting as beneficial and conducive to freedom, the other part claims higher organizational pressure and a feeling of loneliness and missing social interaction [23]. It is a question how the sudden transition into home office changed the working style and the perception of aspects of home office over time through lockdown and non-lockdown phases in 2020. Hence, the study in this paper is conducted to have a look on whether patterns of perceptions during lockdown are significantly different from those in non-lockdown phases and whether there is a difference in managers and employees. The reason to look on the Czech Republic is due to the fact that it went through two lockdown phases in the year 2020. Thus, the research objective in general is to analyse the impact of forced home office during the year 2020 in lockdown and non-lockdown phases on managers and employees. The existing literature suggests that, although already mentioned in the 1980, research did not focus on managers on telecommuting but rather on how managers should work with telecommuting employees [24] similar to the COVID19 pandemic, where mental health issues were usually discussed for employees, not for managers [25]. Hence, it is the purpose of this paper to contribute to the existing research gap in this field.

\section{Materials and Methods}

\subsection{Literature Review}

\subsubsection{Telecommuting and Home Office}

Telecommuting frameworks were subject to studies prior to the COVID-19 crisis. The term telecommuting is used for employees that are not bound to offices and may work from wherever they are at the given moment [26]. On the contrary, home office is bound to the home of each individual. For some individuals a higher degree of individualism and liberty in life allows for a lower degree of psychical stress in home office [27]. For individ- 
uals with a lower degree of discipline the productivity and work quality may decrease. Individuals that were forced into home office due to measures taken against the COVID-19 pandemic were found to suffer a lack of motivation to work alone [28]. Furthermore, their homes might not have even been equipped with the required IT infrastructure to allow for organizing a working atmosphere [29].

Studies on telecommuting show an ambiguous picture. A negative outcome of an extensive home office working is increased risk of social isolation [30], as well as a higher risk of psychical depressions [31], independent from the age of the worker [10]. A study by Bentley et al. show that social isolation may be prevented by communication and support from within the company [32]. The required social interaction with colleagues and the rest of the team has to be provided and guided by the company managers. In order to reduce the feeling of isolation, research suggests to enhance technical support of the worker to provide the worker with the feeling to belong to the team [14].

Lengen et al. propose an approach that is based on a support from managers for their workers bound in home office. Technical support is a basis for meeting the technical requirements of the employees [14]. However, the set of activities and measures proposed shows an approach that is working on a bureaucratic and regular working environment. It includes the support from trained medical and psychological personnel and from official government channels. Due to the circumstances and the external pressure, prior psychological preparation could not be granted to the employees before they went into their home offices [21]. It was observed that this led to a disengagement with their work [33].

Research of the last years has shown that telecommuting, including home office jobs, is subject to stigmatisation, accompanied by prejudices. Promotion chances seem to decrease for employees working in a telecommuting environment in comparison with office jobs [34]. Studies showed that only a minority of managers was coming from a telecommuting working background or was working in telecommuting in the moment that they were sent on home office [35]. Besides the lower degree of prestige these managers were also forced to home office without prepared support, but should support their own subordinates [14].

Already in 1987, a study found that managers and employees were hesitant in accepting telecommuting for their work. Assuming lacking company support and missing social interaction were the two main issues, managers had a more negative attitude [24]. In order to adopt a telecommuting framework, companies have to undergo major cultural change [36]. This requires managers to be properly prepared and trained to manage their team in a bidirectional telecommuting relationship [37]. As telecommuting also means to put trust into the telecommuters by eliminating non-stop visible control [38]. As managers on telecommuting is a research topic not widely present in current literature, the COVID-19 pandemic provides the suggestion that home office harms managers more than their employees as far as mental health is concerned [25]. Managers have been found to have a higher risk of depression and stress in general, being anxious of being isolated, and not being supported by the company [24]. The COVID-19 pandemic makes it difficult for managers striving for a stable environment, forcing them to go suddenly to unprepared home offices.

The COVID-19 pandemic enhanced the speed of transition from office jobs to home office for a vast amount of people [39]. With the COVID-19 pandemic, the speed of transition was increased [40]. Due to its sudden nature, the preparation phase for the transition had to be omitted [41]. While research anticipated the shift towards a higher degree of telecommuting and home office work in several research studies before the pandemic 2020 [42-44], the organizational preconditions were in a vast number of cases non-existent. Following the above-mentioned, the following hypothesis are stated:

Hypothesis 1 (H1). Employees and managers having been on telecommuting before will show a lower degree of negative impacts from forced home offices. 
Hypothesis 2 (H2). Managers will show a higher inclination towards depression and negative adaptive behaviour in home offices than other employees.

Hypothesis 3a (H3a). A higher degree of company preparedness will go in line with a positive self-perception of the situation.

Hypothesis $\mathbf{3 b}(\mathbf{H} 3 \mathbf{b})$. A higher degree of company preparedness will lead to a higher degree of desired home office days of the personnel.

\subsubsection{Workplace Digitalization}

The applied changes evoked challenges for employees and managers in companies. While digitalization of workplaces was predicted to come with the realization of industry 4.0 [45], the COVID-19 pandemic and the governmental countermeasures taken facilitated the digitalization [46]. The use of digital infrastructure for work, communication, learning, customer-relations, and further areas required managers and employees to adapt to the new circumstances. These changes had to be implemented suddenly, while research for the transition towards 4.0 assumed gradual changes [47]. With the sudden shift to home offices, it took companies time to regain control over the situation and their businesses. In that time private households' energy consumption increased, while researchers noted also an increased demand for remote and distance production operation, in order to be able to work from home [48].

Companies that were coming from a digital background and companies that were working with digital platforms [9] were able to withstand the pressure [49] arising from government-imposed restrictions. Companies that already had experience in digitalization work, processes, and infrastructure were able to make better use of the new framework [50]. The trend towards digitalizing businesses and processes that began prior to the crisis was sped up [51]. Various studies in the pre-COVID-19-pandemic era indicated that home office and flexible working hours may be able to increase motivation, efficiency, and satisfaction from work [14,52].

Already in July 2020, Dwivedi et al. emphasized the needs for companies to make use of the new opportunities of digitalization arising from the pandemic shock. Research found employees were taking the potentials of combining private life and work with gratitude [9]. On the contrary, due to social distancing policies the situation may also lead to the cutting and deterioration of social relations [44]. Social distancing is anticipated to be the measure to reduce infection spreading [53], while the cost of this measure has to be borne by society and economy.

Keeping in mind the additional requirements on coordination and telework, these requirements were likewise put on the shoulders of managers and employees [54]. Employees to a certain extent welcomed the newly arising opportunities and the flexibility [9]. At the same time, studies found the amount of daily working hours to increase [55]. Negative aspects of telecommuting include higher working time and a decrease in motivation for one part of the working population [28]. A research study of IBM showed that it depends on the type of job and the environment itself whether the home office work shows negative effects [56]. However, organizational and technical support is believed to play a major role for the well-being of the employee on telecommuting and on home office work [14].

Studies found that managers have to adapt to the digitalized working environment [57]. While the change in culture was found already in the 1980s to play a major role in the acceptance and success of digitalized working frameworks [24], as was also suggested in later years [36], the role of leadership has to evolve itself to meet the new requirements [58]. A further characteristic of the so-called digital leadership is that decisions and risk assessments have to be made with higher speed [57]. As workplace digitalization promotes worker autonomy [59], managers are struggling to find mechanisms to regain full control over their workers [38]. On the other hand, managers were also assumed to have to promote the implementation phase of telecommuting with their own work [60]. Thus, in the COVID-19 pandemic, managers should rely even more on company support to be able to 
fulfil their usual management tasks and to further support their subordinates. Striving for stability [25], managers are dependent on company support and might therefore show a different perception towards the level of granted support.

Companies in several countries in Europe applied the instrument of short work in order to cope with the arising cost [61]. Missing colleagues and team members in the organization put a further burden on the workers on home office. The disruption and the different approaches in the organization led to a further feeling of missing organization and missing support [23]. The autumn wave of the COVID-19 pandemic as the second wave in Europe struck in several countries. Companies and governments had the potential to prepare for this during the summer period. Hence, it is a question whether and to what extent this shows off in the perception of employees and managers with regard to technical support and with regard to company preparedness for the situation.

Following the above-mentioned, the following hypothesis is stated:

Hypothesis 4a (H4a). Employees and managers will have a significantly different perception on company preparedness in lockdown and non-lockdown phases.

Hypothesis $4 \mathbf{b}(\mathbf{H} 4 \mathbf{b})$. Employees and managers will have a significantly different perception on company readiness in lockdown and non-lockdown phases.

\subsubsection{Mental Health}

With the requirement of a fast and sudden transfer of digitalization to secure a home office framework, the situation put employees and managers under pressure. This led to depressions and further mental diseases [62]. It is known from telecommuting frameworks that a substantial part of employees is suffering from mental diseases. These employees communicate with their company exclusively by phone or by notebook, as they do not have a fixed working place [10]. This part of employees is supposed to not be able to profit from the framework, suffering from the negative aspects of telecommuting and home office, such as social isolation and depression [44]. For the part of society that is not inclined to suffer from the negative aspects, such a framework may seem beneficiary for both sides $[9,14,52]$.

Research from Canada suggests that during the COVID-19 pandemic the self-evaluated perception of professionals increased by $100 \%$. Research conducted in several Arabic countries (Oman, Saudi-Arabia, Jordan, Iraq, and Egypt) came to the conclusion that $57 \%$ of the population assumed themselves to be depressive, with no significant differences in the countries [63]. A French survey found out that employees in COVID-19-related professions suffered from depression, anxiety, and stress (DAS). While this was explained by the proximity to COVID-19 patients and the fear of getting infected themselves due to their profession in medical care [17], further studies assumed that other professions and students suffer from DAS [64]. Previous research also suggests a significant difference in gender, with young women under 30 years having a higher risk of getting depressed than males in the same age category [65]. Enhancing factors for depression found were being young and being single [66] and being single and living alone [67]. Similar results were found during the SARS epidemic in Malaysia with medical students [68].

Other approaches to explain the worsening mental state during COVID-19 pandemic cover the findings that the family situation, including physical abuse, plays a higher role than the isolation at home [69]. Italian research found significant evidence that the living situation and the style of a flat are further factors of concern in fostering depression [70]. Several research studies further found past health issues of an individual or of a family member promoted DAS [71-73], with a further boost during government-ordered social isolation [74]. Having family members with current COVID-19 health issues provided an additional risk factor for these people $[75,76]$.

Another group known to suffer depression are managers. This group has been found to belong the group with the highest suicide rates in a study conducted from 2012 to 2015 [77]. Also, in the early phase of the COVID-19 pandemic, managers were found to suffer from DAS, while the management seemed to suffer more than their colleagues on 
lower levels [25]. Managers are also believed to have an impact on the mental health of their staff [78] and might feel in their role that they have to show their strength. Illnesses may take the energy required to cope with the daily job challenges, generating the possibility to fall into depression. Taking into account that the inclination towards DAS seems to rise with the organizational level [25], this suggests only top managers to have a higher inclination towards mental health issues than their employees while trying to keep up their performance [79]. Managers tend to get into stress with sudden changes and seem to need a stable working environment to avoid stress and depression [80]. However, there is still a research gap existing, as mental health is usually discussed in the organizational view of the management function [81]. Requiring stability, it should be assumed that with rising company support and home office readiness managers will stabilize and do not tend to change their way of working again, taking their previous working style. Hence, being sent suddenly to home offices brought managers out of their comfort zone, but it is assumed that with rising company support during the pandemic they would settle into the home office framework like their subordinates [24].

Government-ordered social isolation brought managers and employees into home offices. Both were exposed to risk factors which increase the likelihood of depression and from DAS during their time in home office work in digitalized environments. People who were able to adopt positive adaptive styles in the situation were able to cope with these risks $[82,83]$. People employing negative maladaptive styles have been found to easily suffer from DAS [84,85]. Cognitive and behaviour avoidance as one of the negative maladaptive styles was found to lead to increased depression and stress [86]. Frequentlychanging environments [87] may influence the work and perception of the work and the circumstances of managers and employees [88]. Hence, this article has the objective to examine whether managers and employees show a difference in their stress levels and self-perception of mental health and whether there is a difference in lockdown and non-lockdown phases.

Thus, the following hypotheses are stated:

Hypothesis 5a (H5a). Higher company support levels will lead to a lower degree of missing social interaction.

Hypothesis $\mathbf{5 b}(\mathbf{H} 5 \mathbf{b})$. Higher company support levels will compensate the negative impact on the workers' psyches.

Hypothesis 6 (H6). A higher rating of the contact with the team will lead to a lower perception of negative impacts during the forced home office work.

Hypothesis 7 (H7). Employees and managers will show the same desire to work in home offices with rising company support.

\subsection{Theoretical Framework}

The purpose of this paper is to analyse the outcome of COVID-19 pandemic-enforced home office work on managers and employees. Many employees and managers were forced into home offices and isolation from society as part of social distancing. However, others had already been working in distance-working frameworks, such as telecommuting. Research studies globally showed a variety of negative impacts on different segments of society, including workers $[17,64]$. Among the negative impacts found were a higher degree of depression, anxiety, and stress, an increased feeling of social loneliness, and a higher stress level also during work while being part of a digitalized and decentralized team. However, positive adaptation behaviour and positive circumstances and frameworks might be able to lower the impacts of the afore-mentioned. Hence, it might be assumed that positive framework impacts such as company support and organisation should be able to help managers and employees. 
The research framework further assumes that there are differences between employees being sent to forced home office from a daily office job and employees sent to home office from a telecommuting framework. Telecommuting is assumed to provide higher individual freedom during work paired with a higher individual responsibility for discipline. While this framework might also contain full home office workdays, it also allows for work travels, training on the job, and further personal interaction. Thus, it might be assumed that employees and managers that had been working in telecommuting should have fewer issues when adapting to forced home office work. With this, these segments of employees and managers should have been able to adopt a positive adaptive behaviour, generating a lower level of stress, loneliness, and further negative impacts.

With this, the assumed established theoretical framework may be found in Figure 1 , suggesting a framework where, due to lockdowns, managers and employees used to telecommuting would be able to show lower levels of negative impacts and a higher motivation to work than people coming from a daily office job. People coming from a daily office job might be able to not fall into negativity in cases where they were provided with a high level of company support. The established theoretical framework suggests that the rank of the worker (manager or employee) and the existing or non-existing telecommuting experience should have an impact on the self-perceptions on home office framework and mental health of the workers. However, by experiencing a high level of company support even workers from daily office jobs should tend towards lower negative impacts on their work and their mental health. Telecommuting-experienced workers should be able to accustom to forced COVID-19 home office due to the proximity of telecommuting and home office frameworks. Graphically, this is shown in Figure 1.

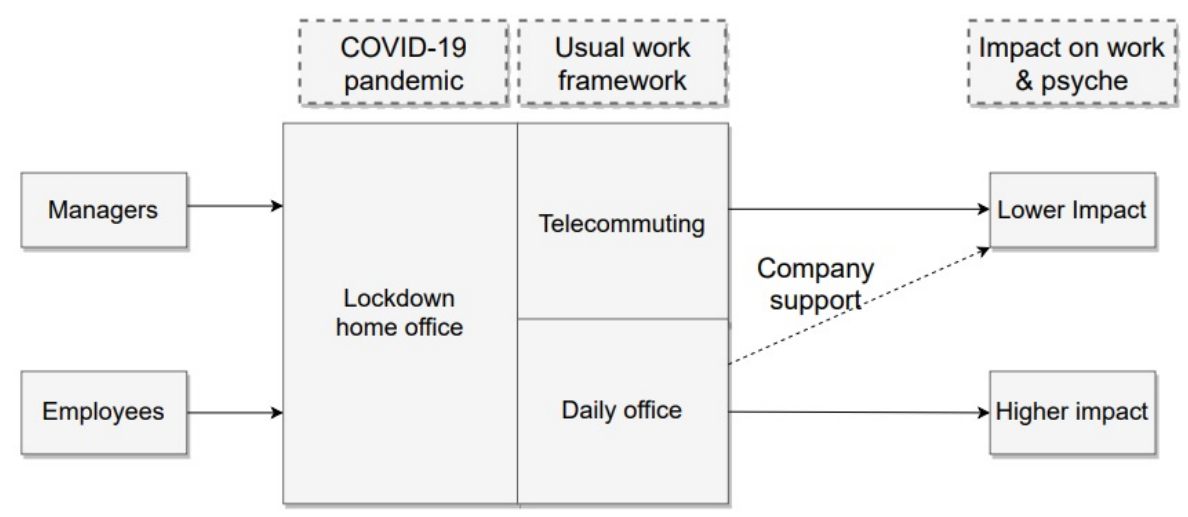

Figure 1. Established theoretical framework (own processing).

The research in this paper focuses on the development of self-perceptions of managers and employees during the COVID-19 pandemic in the Czech Republic. As the Czech Republic went through two lockdowns during the year 2020, this research paper has the objective to observe the development of these self-perceptions in lockdown and nonlockdown times. According to the research framework, the forced home-office framework should lead to a worsening of the psychic state in lockdown and non-lockdown times. In order to examine this, the research monitored self-perceptions during the year 2020 in the machine builder industry. Due to the nature of the machine builder business, large companies with more than 250 employees suit the framework, as does having people in the usual framework of telecommuting, as well as in daily office jobs.

\subsection{Methodology}

The main target of this research study is to gather data on the impact of the COVID-19 pandemic on managers and employees in the Czech Republic with respect to the research questions. The research was conducted with the help of a questionnaire that was given to several industrial corporates. The companies received the same questionnaire each month, asking for the perceptions on lockdowns and on home office frameworks. 
The Czech Republic was one of the first countries to apply measures against the COVID-19 pandemic. The first lockdown was introduced from March to May 2020. During the summer period, the measures were released as overall reported COVID-19 infection numbers remained on a low level. After a rise in autumn, the Czech Republic had to introduce a further lockdown from November onwards [89,90]. Thus, having applied two lockdowns already in 2020, the results of this study might provide valuable data and further insight on the self-perception of employees and managers in lockdowns.

This research study is conducted in order to have a look on the perceptions of managers and employees from the Czech Republic on their working situation during the year 2020. It was anticipated that changes may appear over time between lockdown and nonlockdown periods. Hence, the study was conducted as a longitudinal study. Designed as a longitudinal trend study, it made use of data gathered over time among a similar population with the same questions. This was done in order to monitor and assess the changes of perceptions of the study population over time with the goal of answering the provided research questions.

\subsubsection{Sample}

The survey was conducted in the field of machine and equipment manufacturers in the Czech Republic, corresponding to category 28 of the NACE rev. 2 classification. This is due to the reason that the large machine building companies with more than 250 employees are likely to have part of their employee base on telecommuting, while others are working on a daily office job. The Orbis database contains data on more than 74 million active companies in the whole world, of which more than 3.1 million active companies may be found in the Czech Republic. According to the database, 70 companies were found with at least 250 employees (Table 1). The companies addressed were large manufacturing enterprises registered in the Czech Republic. All of these companies were classified as corporates [91]. The sample was chosen among machine and equipment manufacturers, as these companies make their machines and equipment on order. Thus, these companies have a long order cycle time and hence provide are exposed less to short-time deflections.

Table 1. Basic information on whole study sample [91].

\begin{tabular}{llcc}
\hline$\#$ & Criterion & Number of Companies in Database & Number of Companies in Selection \\
\hline 1 & Status: Active companies in Orbis database & $74,628,856$ & $74,628,856$ \\
2 & World region/Country/Region: Czech Republic & $3,140,781$ & $2,635,878$ \\
3 & Number of employees: min = 250 & 99,334 & 1066 \\
4 & NACE rev. 2, 28 & 293,608 & 38 \\
\hline
\end{tabular}

Approaching the 38 companies in the table, the longitudinal study questionnaire was returned by 174 people from 8 companies. The total number of employees in these companies is 21,875 . Only white collar workers have been asked to fill in the questionnaire. According to the staffing company ManpowerGroup the percentage of population of white collar workers is considered to be $38.4 \%$ in the Czech Republic [92]. A minimum sample size of 161 returned questionnaires was calculated as required. People returning the questionnaire worked in their company as office clerks, sales personnel, and managers on daily basis. Due to the lockdown, these people were sent to home offices and did not return to their office on a regular basis until the end of the year 2020. The survey was conducted once per month in order to monitor the ongoing change of perceptions.

\subsubsection{Variables Definition}

Due to the nature of the dependent variables, these variables underlie the issue of being biased. As the survey asks for a self-perception on different variables based on a five-step Likert scale, the answers underlie a self-bias of the respondents.

Surveys concerning the outcomes of the COVID-19 pandemic, as far as DAS is concerned, made use of the Depression Anxiety Stress Scale (DASS) $21[93,94]$. This standard 
scale also works as a self-reporting tool [95] based on a multi-question score model. Scores are based on a four-step Likert scale for 21 characteristics considered during the DAS rating.

Beside the DAS score, Elbay et al. (2020) also monitor the working conditions in their survey, such as the working hours (weekly working hours as given in number value) and a rating for (a) the support of colleagues and (b) the support of the management. For the self-evaluation of these conditions by the respondees the survey uses six-step Likert scales. These characteristics were used as independent variables for the developed regression model for employees in health care. For higher-ranked personnel, there are similar questions concerning similar conditions on a six-step Likert scale.

As independent input variables, the concerned survey used the gender (male/female) and the question whether children were in the household or not. In addition to the differentiation done during the analysis between managing and working personnel, these variables are also taken over into the research questionnaire used in this paper.

Thus, not being primarily interested in the research of DAS, but taking home office as the trigger for action, this survey is based on the validated questionnaire from Elbay et al. (2020), omitting the DAS score questionnaire by introducing self-perception of the perception of missing social contact and of the perception of negative impacts on the psyche.

In this research, each of the questions was statistically evaluated as a single characteristic:

1. Independent variables

(a) x1: Profession (manager, employee),

(b) x2: Gender (female, male),

(c) x3: Number of children in household,

(d) $x$ 4: Previously working in telecommuting framework.

2. Dependent variables

(i) whether the respondent was currently in home office,

(ii) whether the respondent had already been sent on home office,

(iii) how the respondent perceived the company's technical support,

(iv) how the respondent perceived the company's preparedness for home office.

While question concerning (i) and (ii) were answered on a Likert scale with values 1 to 5, question targeting (iii) and (iv) were of boolean type with the possible answers YES or NO.

(v) how many days did the respondent desired to work in home office at the point of asking,

(vi) how many hours the respondent spent on the telephone during work,

(vii) how many hours the respondent spent on the computer during work,

(viii) what was the main communication means (mobile, computer) with the company.

Questions (v) to (vii) were answered on a Likert scale with values from 0 to 10 resembling the actual hours. The value 10 resembled 10 or more hours per day. Question (viii) was of boolean type.

(ix) how the respondent perceived the actual home office framework,

(x) how the respondent perceived the term home office in general,

(xi) how the respondent perceived the relation with the other colleagues,

(xii) how the respondent perceived the relation with its superior,

(xiii) how the respondent perceived the impact of forced home office on the own mental state,

(xiv) whether the respondent perceived the degree of social interaction as sufficient. Questions concerning (ix) to (xiv) were answered on a Likert scale with values 1 to 5 .

Questions that were answered on the base of a Likert scale all had the same coding. In order to evaluate the characteristics in a further statistical analyses, the answers from the Likert scale were transferred into number values, where 1 was strongly disagree, 2 was disagree, 3 was neutral, 4 was agree, and 5 meant strongly agree. 


\subsubsection{Descriptive Statistics}

Based on the literature review, it might be suggested that females might have a higher inclination towards depression and stress in general than men. Thus, the first independent input variable is the gender. Previously, managers were mostly avoiding telecommuting and home office work due to fear of missing chances of promotion on the job. Now, being forced into home offices, it is unclear whether results on the research questions depend on professional rank, whether the person is a manager or any other office employee. While close family relations are seen to be able to alleviate the feeling of loneliness and missing social interaction, the pressure of children being additionally sent to home schooling into the same flat is also taken into consideration as an input variable. A full overview of the sample with the input variables is shown in Table 2.

Table 2. Basic information on study sample and independent variables gender, profession, number of children.

\begin{tabular}{ccc}
\hline Criterion & Number & Percentage \\
\hline Overall N & 174 & 100 \\
& Gender & \\
Man & 76 & 44 \\
Woman & 98 & 56 \\
Manager & Profession & \\
Employee & 46 & 26 \\
& 128 & 74 \\
1 & Number of children & 10 \\
2 & 17 & 40 \\
3 & 70 & 41 \\
& 72 & 9 \\
Yes & 15 & 30 \\
No & Previous telecommuter & 70 \\
\hline
\end{tabular}

The target of the research was to find out how managers and employees perceived the changes that were going along or that were facilitated by the COVID-19 pandemic with regard to the home office framework. It covered the first spring lockdown period in the Czech Republic and also data for the second autumn lockdown period. Further, it covered the release period during summer 2020. As the pandemic situation changed a few times in the Czech Republic in 2020, there were several challenges to be conquered for the companies and workers. The purpose of this paper is to present the outcomes of this research for the year 2020 while monitoring and data collection will be continued in the next year for a long-term research.

\subsubsection{Statistical Analysis}

The statistical analyses in this paper began with the evaluation of the first section (see sample description, Table 2). Due to the vast amount of data, data is shown in graphs in Appendix A. To gather an overview, categorical variables were summoned showing actual numbers and percentages. According to the time the given dataset was taken, the datasets were further grouped into the phases lockdown 1, non-lockdown, and lockdown 2, functioning as independent variables. Numbers and percentages were also shown in this section.

Due to the binary nature of the independent variables and due to the ordinal character of the input from the rest of the questionnaire, this paper uses non-parametric tests to analyse the gathered data. For the nature of binary and ordinal data, the Kruskal-Wallis test is applied, also known as Kruskal-Wallis H-test. For the further progress of the study, the significance level was set to $p<0.05$. The $H_{0}$ hypothesis assumed the different groups 
of the Kruskal-Wallis test to be equal. A rejection of the $H_{0}$ hypothesis meant that there was a significant difference in the different groups over time.

In order to make use of the Kruskal-Wallis test, the H-test may be approximated by the $\chi^{2}$ distribution [96]. Thus, the critical value with which the test statistics $\mathrm{H}$ was compared belonged to the chi-square distribution for the same amount of degrees of freedom (df). The calculated $p$-value was also derived from the $\chi^{2}$ distribution.

\section{Results}

In order to check the suggestions of the literature review, the independent variables were checked with the non-parametric Kruskal-Wallis test for differences in the different groups of the test. With this, the ordinary dependent variables were tested for whether they showed differences in the self-perceptions of the respondents of the questionnaire. The results may be found in Table 3.

Table 3. Kruskal-Wallis test values for the whole sample.

\begin{tabular}{lcccc}
\hline Hypothesis & df & H Value & Critical $\chi^{\mathbf{2}}$ & $p$-Value \\
\hline H1 & 3 & 35.14 & 0.352 & 0.0000 \\
H2 & 2 & 21.09 & 0.103 & 0.0000 \\
H3a & 3 & 33.33 & 0.352 & 0.0000 \\
H3b & 3 & 30.55 & 0.352 & 0.0000 \\
H4a & 2 & 26.74 & 0.103 & 0.0000 \\
H4b & 2 & 31.73 & 0.103 & 0.0000 \\
H5a & 3 & 6.10 & 0.352 & 0.1068 \\
H5b & 3 & 5.90 & 0.352 & 0.1166 \\
H6 & 3 & 5.32 & 0.352 & 0.1498 \\
H7 & 2 & 17.60 & 0.103 & 0.0001 \\
\hline
\end{tabular}

With the applied Kruskal-Wallis test, a $p$-value $<0.05$ leads to the rejection of the $H_{0}$ hypothesis of the test. The acceptance of the $H_{0}$ hypothesis is taken in the case of a $p$-value $>0.05$. The results suggest that there are significant differences in the analysed data for the whole sample. This means that increased perceptions of company preparedness for home office work and company readiness for digitalization result in increased self-perception of missing social interaction and result in increased self-perception of a worsening psychic state.

While Table 3 shows the Kruskal-Wallis test results for the whole population, the data from managers show differences in a few characteristics. In order to have a look at the managers' perceptions and patterns, the Kruskal-Wallis test was applied with the assumption that the respondent is a manager. The results may be found in Table 4.

Table 4 shows the application of the Kruskal-Wallis test with the assumption of the respondent being a manager. In some characteristics ( $\mathrm{H} 4 \mathrm{a}, \mathrm{H} 5 \mathrm{a})$, the significance differs from the full sample while other characteristics are in line with the sample. This suggests that for the first-named characteristics, managers should be better off than other employees.

In order to check this assumption, the Kruskal-Wallis test is also applied on the data for the employees, presented in Table 5.

Table 5 displays that employees show the same patterns as the whole sample population in Table 3. For hypothesis H3a and H3b, the results differ from the overall sample. This may suggest that employees representing the majority of the workforce have, due to their quantity, a higher influence on the overall sample. While managers have not yet been taken into account for specific studies, this group seems to have different perceptions of their own work, as well as of their own situation. 
Table 4. Kruskal-Wallis test values for managers.

\begin{tabular}{lcccc}
\hline Hypothesis & df & H Value & Critical $\chi^{2}$ & $p$-Value \\
\hline H1 & 2 & 2.67 & 0.103 & 0.2632 \\
H2 & 1 & 7.58 & 0.004 & 0.0059 \\
H3a & 2 & 10.52 & 0.103 & 0.0005 \\
H3b & 2 & 10.23 & 0.103 & 0.0060 \\
H4a & 1 & 2.57 & 0.004 & 0.1089 \\
H4b & 1 & 3.49 & 0.004 & 0.0617 \\
H5a & 2 & 1.58 & 0.103 & 0.4538 \\
H5b & 2 & 1.38 & 0.103 & 0.5015 \\
H6 & 2 & 4.41 & 0.103 & 0.1103 \\
\hline
\end{tabular}

Table 5. Kruskal-Wallis test values for employees.

\begin{tabular}{lcccc}
\hline Hypothesis & df & H Value & Critical $\chi^{2}$ & $p$-Value \\
\hline H1 & 2 & 1.41 & 0.103 & 0.4941 \\
H2 & 1 & 12.70 & 0.004 & 0.0004 \\
H3a & 2 & 4.46 & 0.103 & 0.1075 \\
H3b & 2 & 2.16 & 0.103 & 0.3396 \\
H4a & 12.03 & 0.004 & 0.0005 \\
H4b & 1 & 15.32 & 0.004 & 0.0001 \\
H5a & 2 & 4.63 & 0.103 & 0.0988 \\
H5b & 2 & 4.50 & 0.103 & 0.1054 \\
H6 & 2 & 4.95 & 0.103 & 0.0842 \\
\hline
\end{tabular}

Referring to the research hypothesis of the paper, the following may be summarized in Table 6:

Table 6. Overview of research hypothesis of the paper.

\begin{tabular}{|c|c|c|}
\hline Hypothesis & Description & Accepted/Rejected \\
\hline Hypothesis 1 (H1) & $\begin{array}{l}\text { Employees and managers that have been on } \\
\text { telecommuting before show a lower degree of negative } \\
\text { impacts from forced home office work. }\end{array}$ & Accepted. \\
\hline Hypothesis 2 (H2) & $\begin{array}{l}\text { Managers show a higher inclination towards } \\
\text { depression and negative adaptive behaviour in home } \\
\text { office work than other employees. }\end{array}$ & Rejected. \\
\hline Hypothesis 3a (H3a) & $\begin{array}{l}\text { A higher degree of company preparedness went in line } \\
\text { with a positive self-perception of the situation. }\end{array}$ & Rejected. \\
\hline Hypothesis 3b (H3b) & $\begin{array}{l}\text { A higher degree of company readiness led to a higher } \\
\text { degree of desired home office days of the personnel. }\end{array}$ & Rejected. \\
\hline Hypothesis 4a (H4a) & $\begin{array}{l}\text { Employees and managers have a significantly different } \\
\text { perception on company preparedness in lockdown and } \\
\text { non-lockdown phases. }\end{array}$ & Accepted. \\
\hline Hypothesis $4 \mathrm{~b}$ (H4b) & $\begin{array}{l}\text { Employees and managers have a significantly different } \\
\text { perception on company readiness in lockdown and } \\
\text { non-lockdown phases. }\end{array}$ & Accepted. \\
\hline Hypothesis 5a (H5a) & $\begin{array}{l}\text { Higher company support levels lead to a lower degree } \\
\text { of missing social interaction. }\end{array}$ & Rejected. \\
\hline Hypothesis $5 b$ (H5b) & $\begin{array}{l}\text { Higher company support levels compensate the } \\
\text { negative impact on the workers' psyche. }\end{array}$ & Rejected. \\
\hline Hypothesis 6 (H6) & $\begin{array}{l}\text { A higher rating of the contact with the team leads to a } \\
\text { lower perception of negative impacts during the forced } \\
\text { home office work. }\end{array}$ & Rejected. \\
\hline Hypothesis 7 (H7) & $\begin{array}{l}\text { Employees and managers show the same desire to } \\
\text { work on home office. }\end{array}$ & Rejected. \\
\hline
\end{tabular}

\section{Discussion}

This research was conducted with the objective to analyse the impacts of the COVID-19 forced home office frameworks on managers and employees in the machine and equipment manufacturer business. For this, the differences between people coming from a 
telecommuting framework were assumed to show a better adaptability to the COVID-19 circumstances in lockdown and non-lockdown phases. The finding of the analysis shows an overall inclination towards this assumption. However, managers and employees show a difference in their self-perceptions, where managers show a lower score of negative impact on psyche. Managers perceive themselves to have lower negative impacts on psyche. Managers that are assumed not to have telecommuted before seem to be able to adapt a more positive adaptive behaviour. An explanation for this might be the learned discipline and self-organisation behaviour that managers need in their daily office work.

Support from the company, from managers, and from the team in general is assumed to enhance positive adaptive behaviour of the individual. However, neither an increased perception of the company preparedness for digitalization, nor an increased perception of the company readiness for home office by the employee or manager, seemed to confirm this suggestion. While there was no significant difference found between employees and managers concerning these characteristics, improved ratings do not show any positive effect on the characteristic of negative impact on psyche. Interestingly, companies are not able to significantly enhance the situation of their managers and employees. Also, an increasing rating of contact with the team does not lead to significant betterment of the situation. An explanation may be, that companies are not able to compensate the negative impacts of forced home office through their support, without significant differences between lockdown and non-lockdown phases. Thus, the lockdown seems not to be the primary source for negative adaptive behaviour, but the forced home-office instead is of much higher importance.

From the literature review, it might be assumed that managers and employees differ in their perceptions towards company preparedness for digitalization and in their perception towards company readiness for home office. This was confirmed by the analysis. Managers had a significantly higher perception of the preparedness and readiness than employees. It can only be suggested that the effect leading to a self-biased perception is high with managers. Managers have been introducing and implementing measures to enhance preparedness and readiness in the company themselves and may be convinced of the effectiveness of the latter. Employees, however, show in their perception that they do not fully agree with the view of the managers. A further possible explanation might be the significant increase of working hours that employees expect during lockdown times.

Even though the monitored companies are used to telecommuting, these companies seem to have been struggling with the framework for forced home office until the end of 2020. Previous studies came to the conclusion that women had a higher inclination towards negative mental impacts [66-68]. In this study, there could not be found evidence that women would be worse off mentally. However, survey data did neither support gender nor the number of children in the household to show any significance as independent variables. It seems that the forced home-office circumstances puts a higher psychical burden on employees than on managers expressed by the desire to work less on home office. Digital company and colleague support is not able to compensate the negative impacts of forced home office. Support of this is given as telecommuting-experienced employees and managers also show significantly differing perceptions in lockdown and non-lockdown phases.

Referring to the research objective to analyse the impact of forced home office during the year 2020 in lockdown and non-lockdown phases on managers and employees, it may be said that telecommuting-experienced employees and managers show better positive adaptive behaviour. This contributes to the current theory as managers seem to have a higher ability to adapt positively than their employees.Further, managers see the support from the company in the digital framework and for home office work much more positively than employees. Even though, managers are mostly not working in telecommuting frameworks $[14,35]$, their better adaptability to forced home office work shows off in the self-perception scores. Although managers and employees are using digital communication for their daily work, it seems that employees seem to lose grip while managers seem 
content with the situation. This may have led to a certain form of myopia and self-bias, as managers seem to judge their situation based on whether the company management has evolved. Managers are not dealing with the situation as an isolated issue, but they evaluate it on the basis of the company's commitment for support. Hence, understanding the impacts of forced home office and further frameworks is a challenge for managers. Even though employees do also rate company support as better over time, this is not enough to make up for the negative impacts these employees experience.

Graphically, the results of the survey concerning the mean values for the dependent characteristics may be found in Appendix A. Figures A1-A6 show the development of mean values in the course of the year 2020 for the characteristics company readiness, company preparedness for home office, technical support, desire to work, missing social interaction, and the impact on psyche arising from lockdown and non-lockdown phases.

\section{Limitations}

This research survey is subject to strengths and limitations that have to be mentioned. An important strength is the homogeneity of data that was gathered from the same population over several months. The evaluation of the survey is done with hypothesis testing, applying the Kruskal-Wallis test.

Limitations and shortcomings that have to be mentioned are that the questionnaire is limited to the Czech Republic. The sample was concentrated in a small field of application, focusing on machine and equipment manufacturers to suit the requirement of finding companies with an existing telecommuting framework and home office. Hence, the number of approached companies and the number of returned questionnaires remained low. Another limitation to be mentioned is the retrospective acquisition of data for the months March2020 and April-2020. As the survey was not conducted earlier, there was no data available to project or compare the answers to and perceptions are collected by biased self-evaluation. It is not able to compare the situation prior to and during the pandemic. The retrieved data was used to conduct this study focusing on finding significant relationships in order to assess associations.

\section{Conclusions}

The COVID-19 pandemic struck countries and companies in early 2020. This kept employees and managers in home offices for a longer time. Companies that were not prepared for home office work had to develop fast solutions to enforce home office work. While the perception on preparation for home office and the perception of digital readiness of the company improved, employees and managers had been falling into psychic stress.

This psychic stress was already anticipated at the beginning of this paper during the literature review. The literature review showed that already for the framework of telecommuting people have a higher risk of suffering from social isolation. This research showed that for home office work there is an increased perception of social isolation. However, it seems that this perception of social isolation is stronger in lockdown times than it is in non-lockdown phases. Further, the lockdown phase itself seems to increase the psychical stress on employees and managers. The psychical stress perception and the perception of social isolation are closely related.

The situation of a forced and sudden home office as happened in the Czech Republic in the year 2020 allows also for further suggestions. The perception of digital preparedness and the readiness for home office work did not significantly lead to an increase or decrease in the willingness to work in home offices. This means that either the perception may be independent from the willingness to work in home offices or data evaluated did not allow for another conclusion so far. Also, the number of children living in a household and being at home during school closures cannot be considered a criterion for the here-analysed perception of home offices.

The research study itself has not yet come to an end. The research study will continue until the end of the COVID-19 pandemic to monitor further data.It might therefore be that 
some suggestions of these intermediary research results may be overthrown or reverted due to the results of further research.

By end of the year 2020, the respondents of the questionnaires still show a desire to work in a home office framework. The desire to work in home offices was lower at the beginning of the pandemic and in the second lockdown, reaching a $20 \%$ higher level in the non-lockdown phase. It therefore seems that the perception depends more on the lockdown/non-lockdown application than on the home office framework itself. Further research has to determine to which extent the social burden of a lockdown influences the perception of home office working for employees and managers.

The recentness of events and the uniqueness of the situation require further data and research in order to get a more complete picture of the perception of employees. It is unclear whether the perception of this research done in the Czech Republic will have the same values in other countries. Further, the research does not distinguish between different professions that the respondents have. The only question targeting the profession is the question of whether the person is an employee (office clerk) or a manager. While this question led to significant differences in some outcomes, the gender characteristic did not show any significant differences.

Ongoing research has to show to which extent companies are able to diminish the negative impacts of home office work and social isolation and whether there is a development in the near future forced by the COVID-19 pandemic.

Funding: This research received no external funding.

Institutional Review Board Statement: Ethical review and approval were waived for this study due to the complete anonymity of the study.

Informed Consent Statement: Patient consent was waived due to the complete anonymity of the presented data.

Data Availability Statement: The data presented in this study are available in the chapter Results.

Conflicts of Interest: The author declares no conflict of interest.

\section{Abbreviations}

The following abbreviations are used in this manuscript:

DAS Depression, anxiety, and stress

DASS Depression Anxiety Stress Scale

df degrees of freedom

SD Standard deviation

WHO World Health Organization

\section{Appendix A}

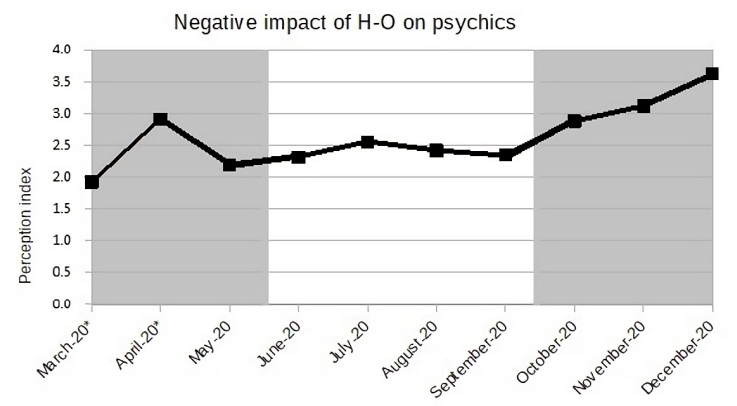

Figure A1. Negative impact of home office on psychics (own processing). 


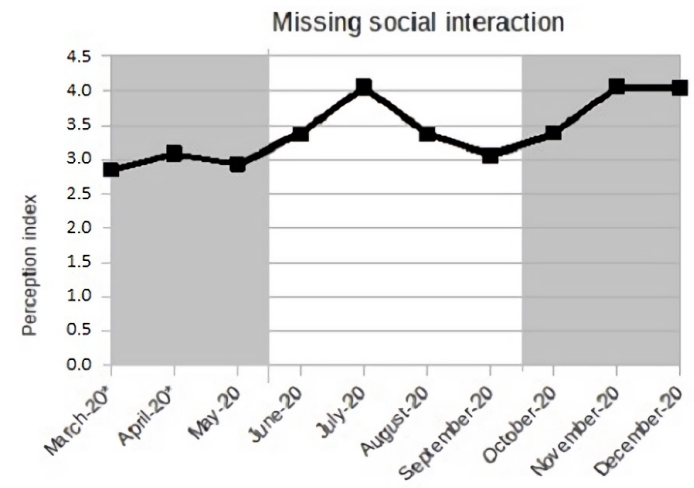

Figure A2. Perception of missing social interaction (own processing).

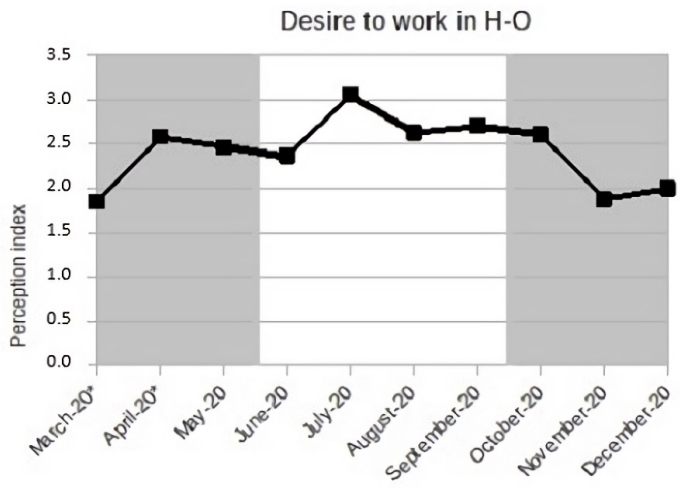

Figure A3. Desire to work in home office (H-O) (own processing).

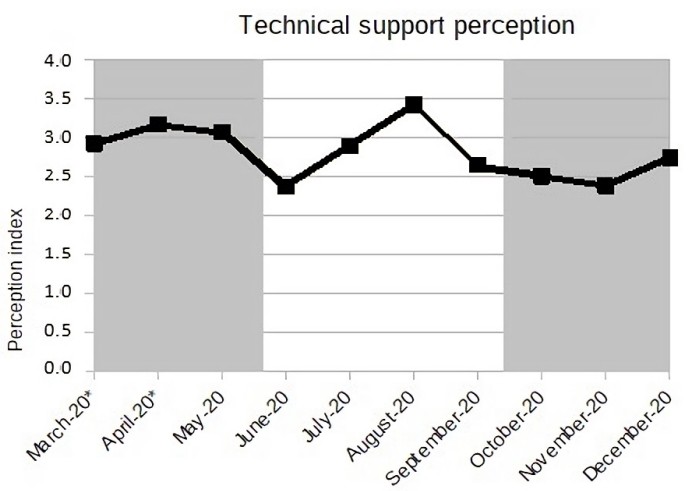

Figure A4. Perception of company's technical support level (own processing).

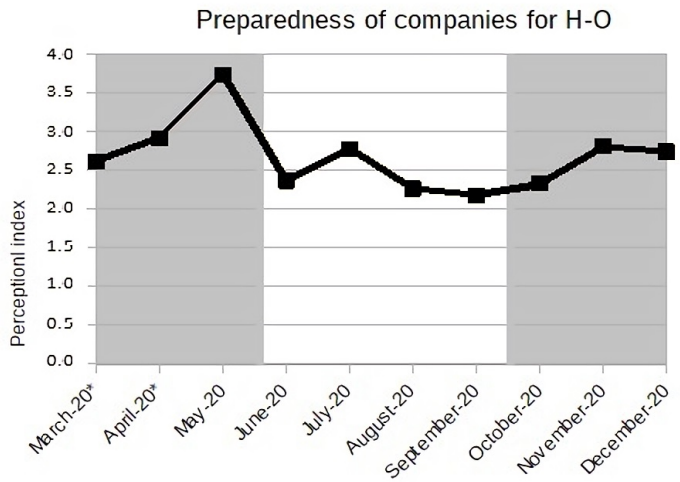

Figure A5. Perception of company's preparedness for home office (H-O) (own processing). 


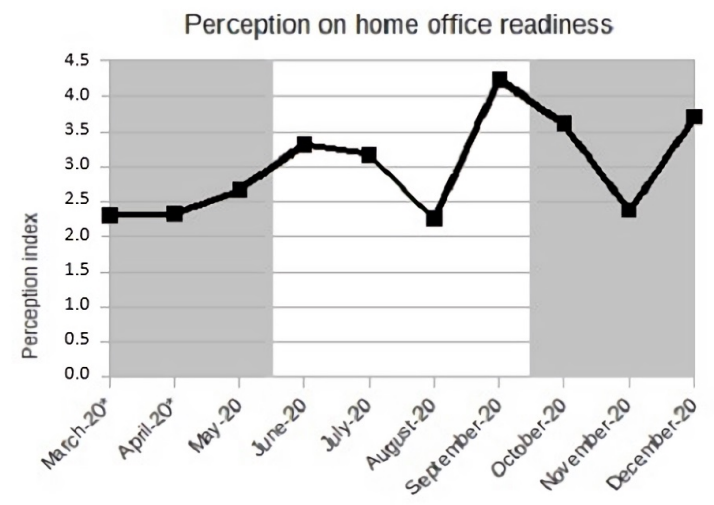

Figure A6. Perception of home office readiness (own processing).

\section{References}

1. WHO. Novel Coronavirus Situation Report 1. 2020. Available online: https://www.who.int/docs/default-source/coronaviruse/ situation-reports/20200121-sitrep-1-2019-ncov.pdf (accessed on 15 April 2021).

2. WHO. Novel Coronavirus Situation Report 41. 2020. Available online: https:/ / www.who.int/docs/default-source/coronaviruse/ situation-reports/20200301-sitrep-41-covid-19.pdf (accessed on 15 April 2021).

3. Lau, H.; Khosrawipour, V.; Kocbach, P.; Mikolajczyk, A.; Schubert, J.; Bania, J.; Khosrawipour, T. The positive impact of lockdown in Wuhan on containing the COVID-19 outbreak in China. J. Travel Med. 2020, 27, taaa037. [CrossRef]

4. Perico, L.; Tomasoni, S.; Peracchi, T.; Perna, A.; Pezzotta, A.; Remuzzi, G.; Benigni, A. COVID-19 and lombardy: TESTing the impact of the first wave of the pandemic. EBioMedicine 2020, 61, 103069. [CrossRef]

5. Atalan, A. Is the lockdown important to prevent the COVID-19 pandemic? Effects on psychology, environment and economyperspective. Ann. Med. Surg. 2020, 56, 38-42. [CrossRef]

6. Domenico, L.D.; Pullano, G.; Sabbatini, C.E.; Boëlle, P.Y.; Colizza, V. Impact of lockdown on COVID-19 epidemic in Île-de-France and possible exit strategies. BMC Med. 2020, 18, 1-13. [CrossRef] [PubMed]

7. Barrios, J.M.; Benmelech, E.; Hochberg, Y.V.; Sapienza, P.; Zingales, L. Civic capital and social distancing during the COVID-19 pandemic. J. Public Econ. 2021, 193, 104310. [CrossRef]

8. Pedersen, M.J.; Favero, N. Social Distancing during the COVID-19 Pandemic: Who Are the Present and Future Noncompliers? Public Adm. Rev. 2020, 80, 805-814. [CrossRef]

9. Dwivedi, Y.K.; Hughes, D.L.; Coombs, C.; Constantiou, I.; Duan, Y.; Edwards, J.S.; Gupta, B.; Lal, B.; Misra, S.; Prashant, P.; et al. Impact of COVID-19 pandemic on information management research and practice: Transforming education, work and life. Int. J. Inf. Manag. 2020, 55, 102211. [CrossRef]

10. Tavares, A.I. Telework and health effects review. Int. J. Healthc. 2017, 3, 30. [CrossRef]

11. Fadel, M.; Salomon, J.; Descatha, A. Coronavirus outbreak: The role of companies in preparedness and responses. Lancet Public Health 2020, 5, e193. [CrossRef]

12. Ågerfalk, P.J.; Conboy, K.; Myers, M.D. Information systems in the age of pandemics: COVID-19 and beyond. Eur. J. Inf. Syst. 2020, 29, 203-207. [CrossRef]

13. Von Gaudecker, H.M.; Holler, R.; Janys, L.; Siflinger, B.; Zimpelmann, C. Labour Supply in the Early Stages of the COVID-19 Pandemic: Empirical Evidence on Hours, Home Office, and Expectations; IZA Discussion Paper No. 13158; Institute of Labor Economics: Bonn, Germany, 2020.

14. Lengen, J.C.; Kordsmeyer, A.C.; Rohwer, E.; Harth, V.; Mache, S. Soziale Isolation im Homeoffice im Kontext der COVID-19Pandemie. Zentralblatt Arbeitsmedizin Arbeitsschutz Ergon. 2020, 1, 63-68. [CrossRef]

15. Brom, C.; Lukavský, J.; Greger, D.; Hannemann, T.; Straková, J.; Švařŕček, R. Mandatory Home Education During the COVID-19 Lockdown in the Czech Republic: A Rapid Survey of 1st-9th Graders' Parents. Front. Educ. 2020, 5, 103. [CrossRef]

16. Koohsari, M.J.; Nakaya, T.; Shibata, A.; Ishii, K.; Oka, K. Working from Home After the COVID-19 Pandemic: Do Company Employees Sit More and Move Less? Sustainability 2021, 13, 939. [CrossRef]

17. Azoulay, E.; Cariou, A.; Bruneel, F.; Demoule, A.; Kouatchet, A.; Reuter, D.; Souppart, V.; Combes, A.; Klouche, K.; Argaud, L.; et al. Symptoms of anxiety, depression, and peritraumatic dissociation in critical care clinicians managing patients with COVID-19. A cross-sectional study. Am. J. Respir. Crit. Care Med. 2020, 202, 1388-1398. [CrossRef]

18. Huemer, U.; Kogler, M.; Mahringer, H. Kurzarbeit als Kriseninstrument in der COVID-19-Pandemie. Kurzexpertise zum Vergleich der Modelle ausgewählter europäischer Länder; WIFO Studies; WIFO: Wien, Austria, 2021.

19. Deutscher Gewerkschaftsbund. Corona und Homeoffice: Wann Darf ich, wann muss ich zu Hause Bleiben und von dort Arbeiten? Fragen und Antworten zum Arbeiten von zu Hause" vom 21; Deutscher Gewerkschaftsbund: Berlin, Germany, 2020.

20. Schulten, T.; Müller, T. Kurzarbeitergeld in der Corona-Krise: Aktuelle Regelungen in Deutschland und Europa; Technical Report, WSI Policy Brief; Hans-Böckler-Stiftung: Düsseldorf, Germany, 2020. 
21. Waizenegger, L.; McKenna, B.; Cai, W.; Bendz, T. An affordance perspective of team collaboration and enforced working from home during COVID-19. Eur. J. Inf. Syst. 2020, 29, 429-442. [CrossRef]

22. Briscese, G.; Lacetera, N.; Macis, M.; Tonin, M. Expectations, Reference Points, and Compliance with COVID-19 Social Distancing Measures; Technical Report; National Bureau of Economic Research, Inc.: Cambridge, MA, USA, 2020. [CrossRef]

23. Newman, S.A.; Ford, R.C. Five Steps to Leading Your Team in the Virtual COVID-19 Workplace. Organ. Dyn. 2021, 50, 100802. [CrossRef]

24. Duxbury, L.; Higgins, C.; Irving, R. Attitudes Of Managers And Employees To Telecommuting. INFOR Inf. Syst. Oper. Res. 1987, 25, 273-285. [CrossRef]

25. Graf-Vlachy, L.; Sun, S.; Zhang, S.X. Predictors of managers' mental health during the COVID-19 pandemic. Eur. J. Psychotraumatol. 2020, 11, 1834195. [CrossRef]

26. Nilles, J.M. Managing Telework: Strategies for Managing the Virtual Workforce; Wiley: New York, NY, USA, 1998 ; Volume 6.

27. Brooks, S.K.; Webster, R.K.; Smith, L.E.; Woodland, L.; Wessely, S.; Greenberg, N.; Rubin, G.J. The psychological impact of quarantine and how to reduce it: Rapid review of the evidence. Lancet 2020, 395, 912-920. [CrossRef]

28. Guan, Y.; Deng, H.; Zhou, X. Understanding the impact of the COVID-19 pandemic on career development: Insights from cultural psychology. J. Vocat. Behav. 2020, 119, 103438. [CrossRef]

29. Kramer, A.; Kramer, K.Z. The potential impact of the Covid-19 pandemic on occupational status, work from home, and occupational mobility. J. Vocat. Behav. 2020, 119, 103442. [CrossRef]

30. Allen, T.D.; Golden, T.D.; Shockley, K.M. How effective is telecommuting? Assessing the status of our scientific findings. Psychol. Sci. Public Interest 2015, 16, 40-68. [CrossRef]

31. Probst, T.; Budimir, S.; Pieh, C. Depression in and after COVID-19 lockdown in Austria and the role of stress and loneliness in lockdown: A longitudinal study. J. Affect. Disord. 2020, 277, 962. [CrossRef]

32. Bentley, T.; Teo, S.; McLeod, L.; Tan, F.; Bosua, R.; Gloet, M. The role of organisational support in teleworker wellbeing: A socio-technical systems approach. Appl. Ergon. 2016, 52, 207-215. [CrossRef]

33. Chadee, D.; Ren, S.; Tang, G. Is digital technology the magic bullet for performing work at home? Lessons learned for post COVID-19 recovery in hospitality management. Int. J. Hosp. Manag. 2021, 92, 102718. [CrossRef]

34. Golden, T.D.; Eddleston, K.A. Is there a price telecommuters pay? Examining the relationship between telecommuting and objective career success. J. Vocat. Behav. 2020, 116, 103348. [CrossRef]

35. Mokhtarian, P.L.; Collantes, G.O.; Gertz, C. Telecommuting, residential location, and commute-distance traveled: Evidence from State of California employees. Environ. Plan. A 2004, 36, 1877-1897. [CrossRef]

36. Watad, M.M.; Will, P.C. Telecommuting and organizational change: A middle-managers' perspective. Bus. Process Manag. J. 2003, 9, 459-472. [CrossRef]

37. Ansong, E.; Boateng, R. Organisational adoption of telecommuting: Evidence from a developing country. Electron. J. Inf. Syst. Dev. Ctries. 2017, 84, e12008. [CrossRef]

38. Raffaele, C.; Connell, J. Telecommuting and Co-Working Communities: What Are the Implications for Individual and Organizational Flexibility? In Flexible Systems Management; Springer: New Delhi, India, 2016; pp. 21-35. [CrossRef]

39. Almeida, F.; Santos, J.D.; Monteiro, J.A. The Challenges and Opportunities in the Digitalization of Companies in a Post-COVID-19 World. IEEE Eng. Manag. Rev. 2020, 48, 97-103. [CrossRef]

40. Belzunegui-Eraso, A.; Erro-Garcés, A. Teleworking in the Context of the Covid-19 Crisis. Sustainability 2020, 12, 3662. [CrossRef]

41. Parker, L.D. The COVID-19 office in transition: Cost, efficiency and the social responsibility business case. Account. Audit. Account. J. 2020, 33, 1943-1967. [CrossRef]

42. Kurland, N.B.; Egan, T.D. Telecommuting: Justice and Control in the Virtual Organization. Organ. Sci. 1999, 10, 500-513. [CrossRef]

43. Gajendran, R.S.; Harrison, D.A. The good, the bad, and the unknown about telecommuting: Meta-analysis of psychological mediators and individual consequences. J. Appl. Psychol. 2007, 92, 1524-1541. [CrossRef]

44. Lal, B.; Dwivedi, Y. Homeworkers' usage of mobile phones: Social isolation in the home-workplace. J. Enterp. Inf. Manag. 2009, 22, 257-274. [CrossRef]

45. Schwab, K. The Fourth Industrial Revolution: What It Means, How to Respond. World Economic Forum. 2016. Available online: https: / www.weforum.org/agenda/2016/01/the-fourth-industrial-revolution-what-it-means-and-how-to-respond (accessed on 4 September 2021.)

46. de Lucas Ancillo, A.; del Val Núñez, M.T.; Gavrila Gavrila, S. Workplace change within the COVID-19 context: A grounded theory approach. Econ. Res. Ekon. Istraž. 2020, 34, 2297-2316. [CrossRef]

47. Benešová, A.; Tupa, J. Requirements for education and qualification of people in Industry 4.0. Procedia Manuf. 2017, 11, 2195-2202. [CrossRef]

48. Klemeš, J.J.; Fan, Y.V.; Jiang, P. COVID-19 pandemic facilitating energy transition opportunities. Int. J. Energy Res. 2020. [CrossRef]

49. Constantiou, I.; Marton, A.; Tuunainen, V. Four models of sharing economy platforms. MIS Q. Exec. 2017, 16, $231-251$.

50. Constantiou, I.; Kallinikos, J. New games, new rules: Big data and the changing context of strategy. J. Inf. Technol. 2015, 30, 44-57. [CrossRef] 
51. Grover, V.; Sabherwal, R. Making sense of the confusing mix of digitalization, pandemics and economics. Int. J. Inf. Manag. 2020, 55, 102234. [CrossRef]

52. Gallie, D.; Zhou, Y.; Felstead, A.; Green, F. Teamwork, skill development and employee welfare. Br. J. Ind. Relat. 2012, 50, 23-46. [CrossRef]

53. Nussbaumer-Streit, B.; Mayr, V.; Dobrescu, A.I.; Chapman, A.; Persad, E.; Klerings, I.; Wagner, G.; Siebert, U.; Christof, C.; Zachariah, C.; et al. Quarantine alone or in combination with other public health measures to control COVID-19: A rapid review. Cochrane Database Syst. Rev. 2020, 82, 501-506. [CrossRef]

54. Raišienè, A.G.; Rapuano, V.; Varkulevičiūtè, K.; Stachová, K. Working from Home-Who Is Happy? A Survey of Lithuania's Employees during the COVID-19 Quarantine Period. Sustainability 2020, 12, 5332. [CrossRef]

55. McKeever, V. Coronavirus Lockdowns are Making the Working Day Longer for Many; CNBC: Englewood Cliffs, NJ, USA, 2020.

56. Hill, E.; Ferris, M.; Märtinson, V. Does it matter where you work? A comparison of how three work venues (traditional office, virtual office, and home office) influence aspects of work and personal/family life. J. Vocat. Behav. 2003, 63, 220-241. [CrossRef]

57. Breuer, S.; Szillat, P. Leadership and digitalization: Contemporary approaches towards leading in the modern day workplace. Dialogue 2019, 2019, 24-36.

58. Peladeau, P.; Herzog, M.; Acker, O. The new class of digital leaders. Tech Innov. 2017, 88, 1-10.

59. Cijan, A.; Jenič, L.; Lamovšek, A.; Stemberger, J. How digitalization changes the workplace. Dyn. Relat. Manag. J. 2019, 8, 3-12. [CrossRef]

60. Bayrak, T. IT support services for telecommuting workforce. Telemat. Inform. 2012, 29, 286-293. [CrossRef]

61. Fadinger, H.; Schymik, J. The costs and benefits of home office during the covid-19 pandemic: Evidence from infections and an input-output model for germany. COVID Econ. Vetted Real-Time Pap. 2020, 9, 107-134. [CrossRef]

62. Lenzo, V.; Quattropani, M.C.; Sardella, A.; Martino, G.; Bonanno, G.A. Depression, Anxiety, and Stress Among Healthcare Workers During the COVID-19 Outbreak and Relationships With Expressive Flexibility and Context Sensitivity. Front. Psychol. 2021, 12, 348. [CrossRef]

63. Al Omari, O.; Al Sabei, S.; Al Rawajfah, O.; Abu Sharour, L.; Aljohani, K.; Alomari, K.; Shkman, L.; Al Dameery, K.; Saifan, A.; Al Zubidi, B.; et al. Prevalence and predictors of depression, anxiety, and stress among youth at the time of CoViD-19: An online cross-sectional multicountry study. Depress. Res. Treat. 2020, 2020, 1-9. [CrossRef]

64. Islam, M.A.; Barna, S.D.; Raihan, H.; Khan, M.N.A.; Hossain, M.T. Depression and anxiety among university students during the COVID-19 pandemic in Bangladesh: A web-based cross-sectional survey. PLoS ONE 2020, 15, e0238162. [CrossRef]

65. Ustun, G. Determining depression and related factors in a society affected by COVID-19 pandemic. Int. J. Soc. Psychiatry 2020, 67, 54. [CrossRef]

66. Liu, D.; Ren, Y.; Yan, F.; Li, Y.; Xu, X.; Yu, X.; Tan, S. Psychological impact and predisposing factors of the coronavirus disease 2019 (COVID-19) pandemic on general public in China. Lancet Psychiatry 2020. [CrossRef]

67. Bartoszek, A.; Walkowiak, D.; Bartoszek, A.; Kardas, G. Mental well-being (depression, loneliness, insomnia, daily life fatigue) during COVID-19 related home-confinement-A study from Poland. Int. J. Environ. Res. Public Health 2020, 17, 7417. [CrossRef]

68. Loh, L.; Ali, A.; Ang, T.; Chelliah, A. Impact of a spreading epidemic on medical students. Malays. J. Med. Sci. 2005, 12, 43.

69. Cohen, R.I.S.; Bosk, E.A. Vulnerable youth and the COVID-19 pandemic. Pediatrics 2020, 146, e20201306. [CrossRef] [PubMed]

70. Amerio, A.; Brambilla, A.; Morganti, A.; Aguglia, A.; Bianchi, D.; Santi, F.; Costantini, L.; Odone, A.; Costanza, A.; Signorelli, C.; et al. Covid-19 lockdown: Housing built environment's effects on mental health. Int. J. Environ. Res. Public Health 2020, 17, 5973. [CrossRef] [PubMed]

71. McCracken, L.M.; Badinlou, F.; Buhrman, M.; Brocki, K.C. Psychological impact of COVID-19 in the Swedish population: Depression, anxiety, and insomnia and their associations to risk and vulnerability factors. Eur. Psychiatry 2020, 63, e81. [CrossRef] [PubMed]

72. Rossi, R.; Socci, V.; Talevi, D.; Mensi, S.; Niolu, C.; Pacitti, F.; Di Marco, A.; Rossi, A.; Siracusano, A.; Di Lorenzo, G. COVID-19 pandemic and lockdown measures impact on mental health among the general population in Italy. Front. Psychiatry 2020, 11, 790. [CrossRef] [PubMed]

73. Wu, M.; Xu, W.; Yao, Y.; Zhang, L.; Guo, L.; Fan, J.; Chen, J. Mental health status of students' parents during COVID-19 pandemic and its influence factors. Gen. Psychiatry 2020, 33, e100250. [CrossRef]

74. Solomou, I.; Constantinidou, F. Prevalence and predictors of anxiety and depression symptoms during the COVID-19 pandemic and compliance with precautionary measures: Age and sex matter. Int. J. Environ. Res. Public Health 2020, 17, 4924. [CrossRef]

75. Wang, Z.H.; Yang, H.L.; Yang, Y.Q.; Liu, D.; Li, Z.H.; Zhang, X.R.; Zhang, Y.J.; Shen, D.; Chen, P.L.; Song, W.Q.; et al. Prevalence of anxiety and depression symptom, and the demands for psychological knowledge and interventions in college students during COVID-19 epidemic: A large cross-sectional study. J. Affect. Disord. 2020, 275, 188-193. [CrossRef]

76. Xiong, J.; Lipsitz, O.; Nasri, F.; Lui, L.M.; Gill, H.; Phan, L.; Chen-Li, D.; Iacobucci, M.; Ho, R.; Majeed, A.; et al. Impact of COVID-19 pandemic on mental health in the general population: A systematic review. J. Affect. Disord. 2020, 277, 55-64. [CrossRef]

77. Peterson, C.; Stone, D.M.; Marsh, S.M.; Schumacher, P.K.; Tiesman, H.M.; McIntosh, W.L.; Lokey, C.N.; Trudeau, A.R.T.; Bartholow, B.; Luo, F. Suicide Rates by Major Occupational Group-17 States, 2012 and 2015. MMWR Morb. Mortal. Wkly. Rep. 2018, 67, 1253-1260. [CrossRef] 
78. Greenberg, N. Mental health of health-care workers in the COVID-19 era. Nat. Rev. Nephrol. 2020, 16, 425-426. [CrossRef] [PubMed]

79. St-Hilaire, F.; Gilbert, M.H.; Brun, J.P. What if subordinates took care of managers' mental health at work? Int. J. Hum. Resour. Manag. 2017, 30, 337-359. [CrossRef]

80. McCann, L.; Hassard, J.; Morris, J. Middle Managers, the New Organizational Ideology and Corporate Restructuring: Comparing Japanese and Anglo-American Management Systems. Compet. Chang. 2004, 8, 27-44. [CrossRef]

81. Byrne, A.; Dionisi, A.M.; Barling, J.; Akers, A.; Robertson, J.; Lys, R.; Wylie, J.; Dupré, K. The depleted leader: The influence of leaders' diminished psychological resources on leadership behaviors. Leadersh. Q. 2014, 25, 344-357. [CrossRef]

82. Baloran, E.T. Knowledge, Attitudes, Anxiety, and Coping Strategies of Students during COVID-19 Pandemic. J. Loss Trauma 2020, 25, 635-642. [CrossRef]

83. Zhu, J.; Sun, L.; Zhang, L.; Wang, H.; Fan, A.; Yang, B.; Li, W.; Xiao, S. Prevalence and Influencing Factors of Anxiety and Depression Symptoms in the First-Line Medical Staff Fighting Against COVID-19 in Gansu. Front. Psychiatry 2020, 11, 386. [CrossRef] [PubMed]

84. Holz, N.E.; Boecker, R.; Jennen-Steinmetz, C.; Buchmann, A.F.; Blomeyer, D.; Baumeister, S.; Plichta, M.M.; Esser, G.; Schmidt, M.; Meyer-Lindenberg, A.; et al. Positive coping styles and perigenual ACC volume: Two related mechanisms for conferring resilience? Soc. Cogn. Affect. Neurosci. 2016, 11, 813-820. [CrossRef] [PubMed]

85. Mahmoud, J.S.R.; Staten, R.; Hall, L.A.; Lennie, T.A. The relationship among young adult college students' depression, anxiety, stress, demographics, life satisfaction, and coping styles. Issues Ment. Health Nurs. 2012, 33, 149-156. [CrossRef] [PubMed]

86. Zimmermann, M.; Bledsoe, C.; Papa, A. The impact of the COVID-19 pandemic on college student mental health: A longitudinal examination of risk and protective factors. PsyArXiv 2020. [CrossRef]

87. Bontempi, E. The europe second wave of COVID-19 infection and the Italy "strange" situation. Environ. Res. 2021, 193, 110476. [CrossRef]

88. Ruktanonchai, N.W.; Floyd, J.R.; Lai, S.; Ruktanonchai, C.W.; Sadilek, A.; Rente-Lourenco, P.; Ben, X.; Carioli, A.; Gwinn, J.; Steele, J.E.; et al. Assessing the impact of coordinated COVID-19 exit strategies across Europe. Science 2020, 369, 1465-1470. [CrossRef]

89. Plaček, M.; Špaček, D.; Ochrana, F. Public leadership and strategies of Czech municipalities during the COVID-19 pandemicmunicipal activism vs municipal passivism. Int. J. Public Leadersh. 2020, ahead-of-print. [CrossRef]

90. Špaček, D. Public administration characteristics in the Czech Republic. In The Public Administration in the EU 27: An Insight in the Characteristics, Capacity and Performance of EU Public Administrations; European Commission: Brussels, Belgium, 2020.

91. van Dijk, B. Orbis—Company Information across the Globe; Bureau van Dijk: Brussels, Belgium, 2021.

92. ManpowerGroup. Total Workforce Index Czech Republic; ManpowerGroup: Milwaukee, WI, USA, 2018.

93. Elbay, R.Y.; Kurtulmuş, A.; Arpacioğlu, S.; Karadere, E. Depression, anxiety, stress levels of physicians and associated factors in Covid-19 pandemics. Psychiatry Res. 2020, 290, 113130. [CrossRef]

94. Sarıçam, H. The psychometric properties of Turkish version of Depression Anxiety Stress Scale-21 (DASS-21) in health control and clinical samples. J. Cogn. Behav. Psychother. Res. 2018, 7, 19-30.

95. Lovibond, P.; Lovibond, S. The structure of negative emotional states: Comparison of the Depression Anxiety Stress Scales (DASS) with the Beck Depression and Anxiety Inventories. Behav. Res. Ther. 1995, 33, 335-343. [CrossRef]

96. Spurrier, J.D. On the null distribution of the Kruskal-Wallis statistic. J. Nonparametr. Stat. 2003, 15, 685-691. [CrossRef] 